\title{
Pedagogic Aspects in Nursing Education: Integrative Review
}

\author{
Jennifer Rojas Reyes \\ Luz Nelly Rivera Álvarez ${ }^{2}$ \\ María José Morera Pomarede 3
}

\section{Pedagogic Aspects in Nursing Education: Integrative Review}

Objective. To know the current state of development of the thematic area of nursing education related with professional training and to determine the research trends. Methods. Descriptive integrative review, which conducted a search in databases limited from 2005 to 2016, using MeSH and DeCS terms, like Nursing, education, Nursing education research, Nursing students, health knowledge practice, and professional competence, which analyzed 50 original articles. Results. The concepts that emerged were: successful didactics, caring learning process, professional skills, professor role, and pedagogic relationships. The highest levels of evidence were found in studies on didactics; however, the trends and challenges of this review are aimed at the professional skill because it becomes the transversal concept in the formation of nurses. Conclusion. The thematic area of nursing education related with professional training has advanced in the development and level of evidence on the

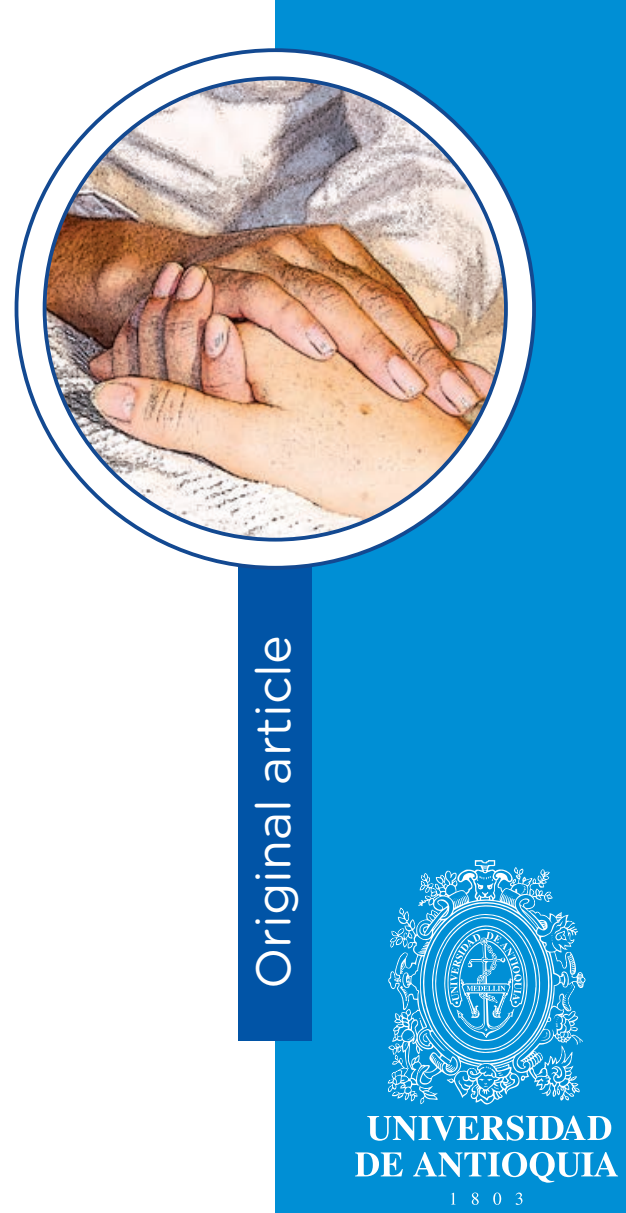

1 Nurse, Ph.D. candidate. Universidad Nacional de Colombia, Bogotá (Colombia). email: jrojasre@unal.edu.co

2 Nurse, Ph.D. Associate Professor, Universidad Nacional de Colombia, Bogotá (Colombia). email: Inriveraa@unal.edu.co

3 Nurse, Ph.D. Full Professor, School of Nursing Sant Joan de Déu, Barcelona (Spain).

email: MMorera@santjoandedeu.edu.es

Conflicts of interest: none.

Article linked to research: "Interpersonal skill of the nursing professor: genesis and mutual influence in the formation of nursing students". Funded by Call 727 of 2015 by COLCIENCIAS for national PhDs.

Received: May 7, 2018

Accepted: September 19th, 2018.

How to cite this article: Rojas J, Rivera LN, Morera MJ. Pedagogic : Rojas J, Rivera LN Morera MJ. Pedagogic Aspects in Nursing Education: Integrative Review. Invest. Educ. Enferm. 2018; 36(3):e03

DOI: 10.17533/udea.iee.v36n3e03

\section{(ब) $\Theta($}


concept of successful didactics, which is why the other concepts have remained in exploration and description whether in quantitative or qualitative studies. All the concepts analyzed have voids and the research trend is aimed at mixed, predictive, and experimental studies that respond well to this theme.

Descriptors: education, nursing; nursing education research; professional competence; learning; teacher training; students, nursing.

\section{Aspectos pedagógicos en la formación de Enfermería: Revisión integrativa}

Objetivo. Conocer el estado actual de desarrollo del área temática de educación en enfermería relacionada con la formación profesional y determinar las tendencias para la investigación. Métodos. Revisión integrativa descriptiva, en la que se realizó una búsqueda en bases de datos entre los años 2005 - 2016, utilizando términos MeSH y DeCS como Education nursing, Nursing education research, 7Students nursing, Health knowledge practice y professional competence, en el que se analizaron 50 artículos originales. Resultados. Emergieron conceptos como: didácticas exitosas, proceso de aprendizaje del cuidado, competencias profesionales, rol docente y relaciones pedagógicas. Los mayores niveles de evidencia se encuentran en los estudios sobre didácticas, sin embargo, las tendencias y retos de esta revisión se orientan hacia la competencia profesional porque se convierte en el concepto transversal en la formación de enfermeros. Conclusión. En el área temática de educación en enfermería relacionada con la formación profesional se ha avanzado en el desarrollo y nivel de evidencia en el concepto de didácticas exitosas, por lo que los otros conceptos se han quedado en exploración y descripción ya sea en estudios cuantitativos o cualitativos. Todos los conceptos analizados presentan vacíos y la tendencia en investigación se orienta a estudios mixtos, predictivos y experimentales que den respuesta a esta temática. 
Descriptores: educación en enfermería; investigación en educación en enfermería; competencias profesionales; formación del profesorado; aprendizaje; estudiantes de enfermería.

\section{Aspectos pedagógicos na formação de Enfermagem: Revisão integrativa}

Objetivo. Conhecer o estado atual de desenvolvimento da área temática de educação em enfermagem relacionada com a formação profissional e determinar as tendências para a investigação. Métodos. Revisão integrativa descritiva, na qual se realizou uma busca em bases de dados limitando entre os anos 2005 - 2016, utilizando términos MeSH e DeCS como Education nursing, Nursing education research, Students nursing, Health knowledge practice e professional competence, no qual se analisaram 50 artigos originais. Resultados. Os conceitos que emergiram foram: didáticas de sucesso, processo de aprendizagem do cuidado, competências profissionais, papel docente e relações pedagógicas. Os maiores níveis de evidência se encontram nos estudos sobre didáticas, embora as tendências e retos desta revisão se orientam para a competência profissional porque se converte no conceito transversal na formação de enfermeiros. Conclusão. $\mathrm{Na}$ área temática de educação em enfermagem relacionada com a formação profissional se há avançado no desenvolvimento e nível de evidência no conceito de didáticas de sucesso, pelo que os outros conceitos se hão quedado em exploração e descrição já seja em estudos quantitativos ou qualitativos. Todos os conceitos analisados apresentam vazios e a tendência em investigação se orienta a estudos mistos, preditivos e experimentais que deem resposta a esta temática

Descritores: educação em enfermagem; pesquisa em educação de enfermagem; competência profissional; aprendizagem; capacitação de profesores; estudantes de enfermagem. 


\section{Introduction}

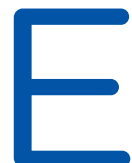

ducation is an attribute implicit in nursing; it is a characteristic seal of the profession to design innovative educational strategies for health regarding the population's needs for care; however, when referring to teaching - learning processes within nursing, it is difficult to respond to this aspect, given that managing to teach others of how and what care is requires knowledge and pedagogic skills, which is why a discipline like nursing is nourished by another, like pedagogy for the formation of competent nurses. Education is an action that manifests the intentionality of the progressive social improvement that permits humans to develop their potentialities, ${ }^{(1)}$ which is why teaching - learning processes invite to a collective construction that promotes active participation of students and professors, where as human beings they bring experiences, where the learn, unlearn, and teach. ${ }^{(2)}$

For some authors who have addressed the theme, ${ }^{(3-5)}$ nursing education constitutes the foundation for the profession's progress, hence, formation must guarantee the preparation of professionals who identify with their work, with high professional self-concept, and who manage their own work environments, so that nursing as a profession becomes visible and acquires the social recognition it deserves. Given the needs expressed and the educational and contextual transformations, research is necessary on themes related with the formation of nurses, thus, some questions guiding this review were: What is the current state of development of the thematic area of nursing education? What are the knowledge voids around nursing education? What are the research trends and challenges in this field?

To answer these questions, the integrative review had as objectives that of knowing the current state of development of the thematic area of nursing education related with the professional training during the period from 2006 to 2016, presenting the findings of the scientific selections, the contrast among their similarities, their theoretical and methodological approaches, and the knowledge voids found regarding nursing education for professional training and determining the trends and/or challenges for research in this field.

\section{Methods}

A descriptive integrative review ${ }^{(6)}$ was conducted to answer the question: What is the current state of scientific knowledge around nursing education aimed at professional training and what research voids derive from these results? The search was carried out in the Embase, Science direct, Pubmed, Medline, Academic search complete, PsycARTICLES, BVS, LILACS, Scielo, 
Scopus, and ERIC databases in English, Spanish, and Portuguese and limited to between 2005 and 2016. This time range was selected because it permits encompassing the evolution and current state of the theme, which in nursing is relatively novel. The review used the DeCS and MeSH terms of Education, Nursing, Nursing education research, Nursing students, Health knowledge practice, and Professional competence, performing the search with equations using Boolean operators of AND and OR.

Inclusion criteria for this review were original articles or those derived from research on the theme of nursing education for the formation of professionals, which included subjects, like professors and/or nursing students, during the time lapse already described and seeking to encompass the highest number of articles that could be accessed in full text. The review excluded textbooks and thesis works because of their extension, as well as reflexion and review articles because these lacked the level of evidence resulting from research processes and which was catalogued according to the Joanna Briggs Institute $(\mathrm{JBI}) .{ }^{(7)}$ The strategy for search and selection of articles is detailed in Figure 1.

\section{Literature Review $n=705$}

Embase, Science direct, Pubmed, Medline, Academic search complete, PsycARTICLES, BVS, LILACS, Scielo, Scopus and ERIC

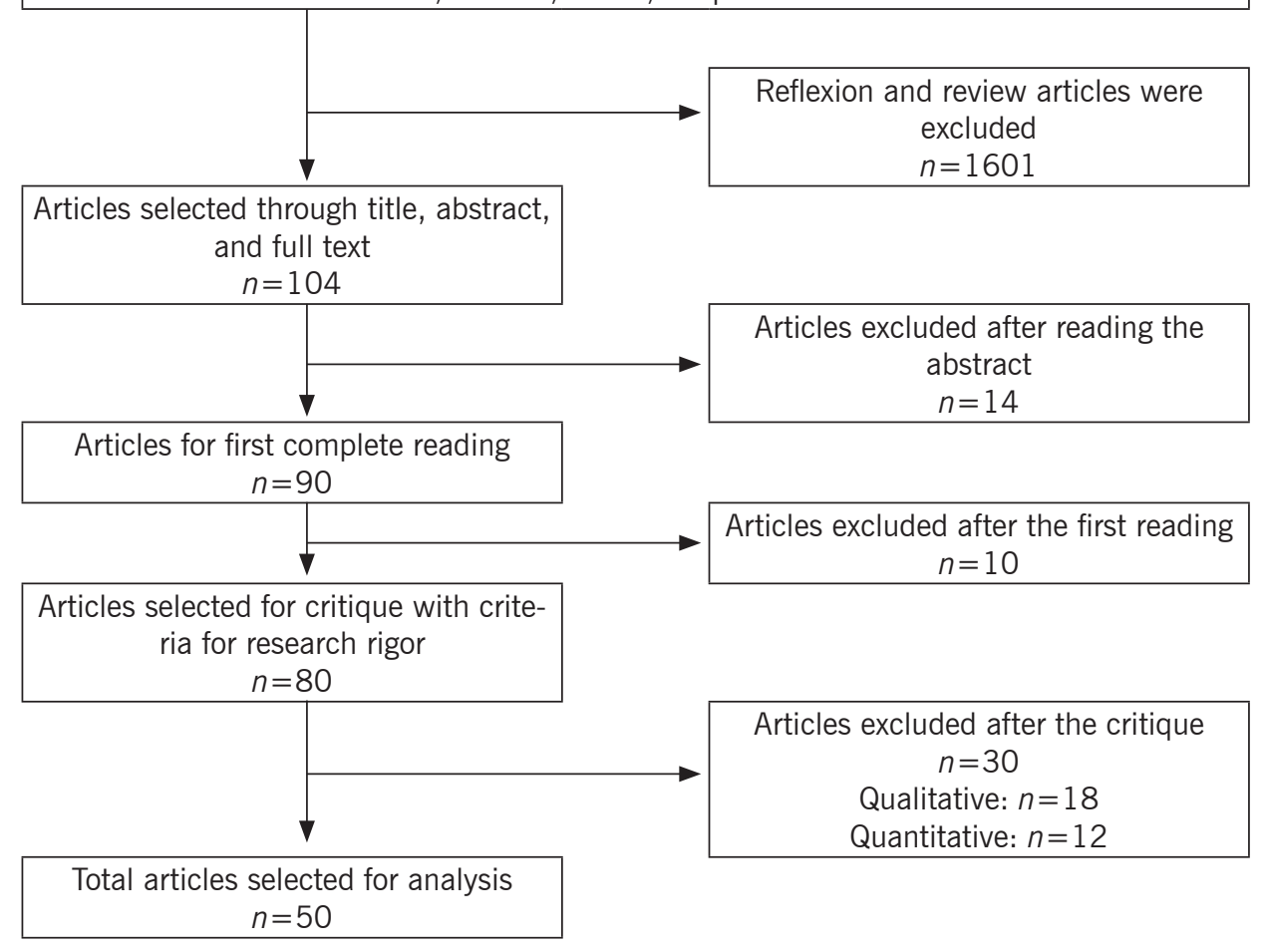

Figure 1. Flow diagram of the article search and selection strategy 
To analyze the information, the articles were collected in the Microsoft Excel program, creating a matrix where a critique and analysis of these was made. To critique the quality of an article, research rigor criteria were used, bearing in mind its approach and verifying the level of evidence provided according to the JBI. For qualitative studies, the Guba(8) criteria of credibility, transferability, dependence, and confirmability were applied. In quantitative studies, criteria of internal, external, construct, and statistic validity ${ }^{(9)}$ were used starting by reading the information provided in the methods and results sections of the research reported.

With respect to the analysis of the theme addressed in the articles to develop the matrix, the following variables were defined: research approach, study design, method of gathering data, analysis employed, their principal results and conclusions; thereafter, with this information condensed, the review followed the steps exposed by Guirao, Olmedo, and Ferrer, ${ }^{(6)}$ which include organizing, labelling, integrating, and prioritizing to define the principal concepts.

\section{Results}

The bibliographic search in the databases yielded 1705 articles of which 104 were chosen through title and abstract relevance. After a first reading of the full article, 80 of these were critiqued through rigor criteria already mentioned; of these, 30 were excluded, 12 quantitative reports that mostly had faults in their internal and statistic validity, and 18 qualitative reports that do not clarify their confirmability of the data or such was doubtful. In the end, 50 articles were analyzed, given that they were research results or original articles that address the thematic area of the formation of nurses.

From the literature review, it was possible to determine the categories or principal concepts of the research conducted on nursing education.
This analysis process had the following phases: (i) Organization and denomination: organized the information by common characteristics, assigning a name to each group of articles that were related through their content and which configured a nuclear aspect of nurse formation. The denomination of each group was the reflexion of the theme or central research concept. The following categories and analysis concepts emerged from this initial phase: (1) didactics; (2) nursing education; (3) learning process; (4) clinical professor; ${ }^{(5)}$ pedagogic relationships; (6) evaluation of the professor; ${ }^{(7)}$ professor skills and nursing skills; (ii) Integration: upon formalizing and denominating the groups, the different groups were integrated, having as criteria their thematic and/or methodological affinity, obtaining five categories or groups, that is: (1) successful didactics; ${ }^{(2)}$ the caring - learning process; (3) the nurse's professor role; (4) pedagogic relationship; and ${ }^{(5)}$ professional skills; and (iii) Prioritizing: this phase organized the information according to the level of scientific evidence found in their results, an aspect reflected in Table 2, according to the $\mathrm{JBI} .{ }^{(7)}$

Regarding the methodological distribution of the articles after their integration in the principal concepts, it may be noted in Table 1 that the concepts most-often addressed were that of successful didactics with $32 \%$ and professional skills with 24\%; the concept with the least amount of articles found was that of professor role with $8 \%$. Qualitative research prevailed in methodological approach with $58 \%$ of the total analyzed; additionally, it is observed that $34 \%$ contributes from the quantitative nonexperimental a contribution to the descriptivetype evidence. Merely 2\% (one article) had experimental research and meta-analysis reports in the concept of didactics, being the only concept with a level of evidence 1 , according to the JBI classification for effectivity studies. 
Table 1. Distribution of 50 articles reviewed according to the methodology employed and the principal concept principal addressed

\begin{tabular}{lccccc}
\multicolumn{1}{c}{ Concepts } & $\begin{array}{c}\text { Qualitative } \\
n(\%)\end{array}$ & $\begin{array}{c}\text { Non-experimental } \\
\boldsymbol{n}(\%)\end{array}$ & $\begin{array}{c}\text { Quantitative } \\
\text { Experimental } \\
\boldsymbol{n}(\%)\end{array}$ & $\begin{array}{c}\text { Meta-analysis } \\
\boldsymbol{n}(\%)\end{array}$ & $\begin{array}{c}\text { Total } \\
\boldsymbol{n}(\%)\end{array}$ \\
Successful didactics & $9(56.2)$ & $5(31.2)$ & $1(6.3)$ & $1(6.3)$ & $16(32.0)$ \\
Caring learning process & $2(22.2)$ & $7(77.8)$ & 0 & 0 & $9(18.0)$ \\
Nurse's professor role & $2(50.0)$ & $2(50.0)$ & 0 & 0 & $4(8.0)$ \\
Pedagogic relationship & $7(77.8)$ & $2(22.2)$ & 0 & 0 & $9(18.0)$ \\
Professional skills & $9(75.0)$ & $3(25.0)$ & 0 & 0 & $12(24.0)$ \\
Total & $29(58.0)$ & $17(34.0)$ & $1(2.0)$ & $1(2.0)$ & $50(100.0)$ \\
\hline
\end{tabular}

Table 2 presents the central concepts identified in the review with the research themes that support each concept and their predominant level of evidence. The $\mathrm{JBI}(7)$ classifies the levels of evidence according to the research results, that is, it establishes separate levels for studies that verify effectivity, diagnosis, prognosis, economic evaluations, and significances; this clarification is made to support understanding the following table.

Table 2. Results of grouping into central concepts, themes researched, and levels of evidence

Central concept

Successful didactics

Caring learning process

Nurse's professor role

Pedagogic relationship

Professional skills

\section{Themes researched}

Didactics framed on the use of narratives and reflexive writing ${ }^{(10-14)}$ Evidence-based practice ${ }^{(15-17)}$

Use of ICTs and virtual learning environments ${ }^{(18-21)}$

Problem-based learning(22-24)

Use of the clinical simulation ${ }^{(25)}$

Reflexive thought of nursing students ${ }^{(26-28)}$

Learning styles of nursing students(29-32)

Critical thought of nursing students ${ }^{(33-35)}$

Significance of being a professor ${ }^{(36-38)}$

Duality between being a professor and being a nurse ${ }^{(39)}$

Importance and significance of the pedagogic relationship between professors and nursing students ${ }^{(40-42)}$

Effect of the pedagogic relationship on learning by nursing students $^{(43-50)}$

Importance and definition of nursing skills ${ }^{(51)}$

Interpersonal and communication skills of nursing professors ${ }^{(52-59)}$

Humanistic and ethical skills ${ }^{(60,61)}$
JBI Level of evidence

Level 3 - In significance

Level $4 b$ - In effectivity

Level 4b - In effectivity

Level $1 b-$ In effectivity

Level $1 c-$ In effectivity

Level 3 - In significance Level $4 b-$ In effectivity Level $4 b-$ In effectivity

Level 3 - In significance Level 4b - In effectivity

Level 3 - In significance Level 3d - In effectivity

Level $4 b$ - In effectivity Level 3d - In effectivity Level 3 - In significance 
With the prior findings, it may be determined that good part of the scientific literature has described and advanced on developing the level of evidence in the following concepts: successful didactics for teaching, aspects of the pedagogic relationship, and professional skills, which is why the other concepts have remained in exploration and description whether quantitative or qualitative.

Table 3 displays the explicit voids and research trends found in the scientific literature review on nursing education

Table 3. Explicit voids of the literature on nursing educational research

\begin{tabular}{|c|c|}
\hline Explicit voids & Research trend \\
\hline $\begin{array}{l}\text { Enhance transpersonal, ethical, and humanistic skills of } \\
\text { caring in the development of students. Aspects related with } \\
\text { skills for caring that are relevant for the formation of nurses } \\
\text { and which favor the teaching - learning process. }\end{array}$ & $\begin{array}{l}\text { The trend is toward the exploration and description } \\
\text { of professional skills, especially in their interpersonal } \\
\text { aspects: How are professional skills developed? What is } \\
\text { needed to develop these skills? What happens with the } \\
\text { interpersonal aspects of the skill? }\end{array}$ \\
\hline $\begin{array}{l}\text { Identify the positive and negative characteristics prevalent } \\
\text { in the pedagogic relationships intervening in the develop- } \\
\text { ment of nursing skills in students. Describe behaviors and } \\
\text { interactions that make the pedagogic relationship beneficial } \\
\text { for learning in nursing. }\end{array}$ & $\begin{array}{l}\text { The trend is aimed at descriptive, comparative, and cor- } \\
\text { relational studies: What aspects of the pedagogic rela- } \\
\text { tionship influence upon learning? What are the behaviors } \\
\text { that characterize an effective pedagogic relationship? } \\
\text { Do factors exist that are associated or predict effective } \\
\text { pedagogic relationships for learning? }\end{array}$ \\
\hline $\begin{array}{l}\text { Preparing a nursing professional is a complex task that re- } \\
\text { quires the professor having skills related not only with their } \\
\text { knowledge, but also with the abilities acquired from their } \\
\text { own experience in terms of being. Nursing education has } \\
\text { voids that do not correspond to student expectations, like } \\
\text { the pedagogic formation of the professors, their behavior and } \\
\text { responsibility related to student learning. }\end{array}$ & $\begin{array}{l}\text { The trend is still descriptive; however, with what has } \\
\text { been found we must advance to predictive, experimental, } \\
\text { or mixed levels: What are the professor's professional } \\
\text { skills and behaviors that favor student learning? What } \\
\text { is the relationship between the professor's professional } \\
\text { skills and the student's perception of learning? What } \\
\text { is the effect of the professor's behavior on the nursing } \\
\text { student's learning experience? }\end{array}$ \\
\hline
\end{tabular}

\section{Discussion}

The following presents the discussion among the relevant findings, explicit voids, and research trends reported in the scientific literature reviewed, from the central concepts resulting from the integrative review.

\section{Successful didactics}

Regarding the concept of didactics, several results are noted on the description and development of pedagogic strategies; thus, prevailing in the use of narratives and other reflexive writings, evidencebased nursing, application of information and communication technologies (ICTs), simulation and problem- or case-based learning, with the last reaching the highest level of evidence in this review. It is important to highlight that all the didactics described have been catalogued as successful. Didactics framed within the narratives and other reflexive writings, like practice diaries and nursing situations, permit students "to let be" within their learning process, that is, it helps them to think and reflect upon what they experience in their practice without structured cognitive demands. ${ }^{(10,11)}$ These writings provide information on the connection students make 
between theory and practice, their fears, their appreciations on the profession, the construction of their professional identity, and perception on the professors' accompaniment. ${ }^{(12-14)}$

For the evidence-based practice, as important didactic within the nursing curriculum, some studies describe that even including this as an assignment, lack of knowledge exists on its use during the professional life; (15) however, this strategy contributes to students improving their abilities in searching for scientific information and solving problems, favoring critical thought. $(16,17)$ With respect to the use of ICTs and virtual learning environments, it is acknowledged that these tools favor the student's autonomy and lead them to seek knowledge on their own. ${ }^{(18,19)}$ In addition, a study on the use of this strategy to solve problems in nursing evidenced that $63 \%$ reached expected levels with respect to the methodologies developed to solve the cases. ${ }^{(20)}$ In spite of the advantages contemplated, the sole use of ICT strategies is not recommended, rather, combined with more conventional didactics; this situation adduces that only e-learning produces dissatisfaction in students during their learning process. $^{(21)}$

Learning based on cases or problems is a didactic approach that promotes the application of theory to practice and the development of abilities to solve problems. Due to the aforementioned, a meta-analysis conducted on the theme found that the size of the effect of this didactic in Nursing education is from medium to high, additionally, representing a high degree of satisfaction with learning. ${ }^{(22)}$ Considering that this didactic is essential to properly identify a problem to manage it appropriately, a non-randomized clinical trial evaluating the student's performance with a simulated patient determined that the intervention group using this didactic strategy developed a better assessment of the patient than the control group using the traditional discussion. ${ }^{(23)}$ Lastly, in the concept of didactics is the clinical simulation as skills assessment tool; ${ }^{(24)}$ it is a highly advanced educational method that promotes technical and relational abilities and increases teamwork capacity, without the possibility of harming the patient, demonstrating that it helps to strengthen the decision making capacity. ${ }^{(25)}$

The review on the concept of didactics demonstrates that it is a widely addressed theme in nursing, that is, progress has been made on "how" to teach to care. Of the forms presented, it may be deducted: (i) students require contact with professors (work in the classroom) and this is why ICTs are a support but not the central axis, hence, highlighting the importance of Blended Learning (B-Learning); (ii) use of simulation and problem-based learning is prevalent, making it considerable to have a long-term follow up of students who use them, and (iii) progress is needed on the research level of the reflexive writings, given their usefulness to reflect on and about the students' actions.

\section{Caring learning process}

For this concept, the levels of evidence provided are of descriptive and correlation type, but generally describe the ways students learn during classes and practices, besides the contexts, mental and psychological processes that lead students to understand and appropriate the disciplinary knowledge. Thus, understanding the essence of the nursing being, the need to advance is clear on teaching aimed on technical aspects toward aspects of therapeutic relationship, the reason why diverse studies focus on strategies that let students develop reflexive thought and change their professional vision. ${ }^{(26,27)}$ When students verbalize their experiences and are guided on that thinking about the action, they manage to develop a conscious attitude of their work regarding the complexity of nursing situations, abandoning automatic actions, achieving significant learning. ${ }^{(28)}$

Connected to the aforementioned, we must keep in mind the learning styles (active, reflexive, theoretical, and pragmatic) in which, for the study by López and Silva, ${ }^{(29)}$ students showing greater 
preference for the reflexive style tended to have higher levels of depth and orientation to the goal. This was supported by another study, which found statistically significant differences in the reflexive $(p=0.002)$ and theoretical $(p<0.0001)$ learning styles with these being of greater preference against active and pragmatic learning styles. ${ }^{(30)}$ Aspects related with students' study habits should also be contemplated, where some investigations concluded that $78.6 \%$ usually studied alone, $85 \%$ report better learning when the theme is of interest, $76.8 \%$ think that practical activities favor their learning, and that in class $55.5 \%$ they always remember more easily the knowledge introduced visually. ${ }^{(31,32)}$

Furthermore, the position of nursing students in the $21^{\text {st }}$ century regarding their teaching learning process points to describing them as active subjects in search of greater political and critical participation as a factor that guides to a profile of nurses with greater social insertion. ${ }^{(33)}$ This projection is the result of a reflexive critical approach in the formation process for which it must be based on new communication and organizational possibilities, as well as on intersubjectivity and care relationships. ${ }^{(34)}$ Diverse investigations on processes of learning about caring have described a student oriented to significant learning through reflexion, where upon being critical of their passage through nursing knowledge they are removed from automatic activities, without leaving aside that in this profession practice is of priority, so that in this aspect the challenge lies in understanding the way students develop care abilities in direct contact with people.

\section{Nurse's professor role}

For this concept, the articles found manage to framework nursing as the differentiating factor within the development of the disciplinary teaching, managing to establish its strengths, weaknesses, skills, and limits, this stems from what it means to be a professor for them and from their prior experiences as nurses. Starting from what it means for the nurse to be a professor, a study describes that it is a way of recognizing themselves in the world as beings that share experiences and that this role includes providing care, distributing tasks, supervising, and supporting students. ${ }^{(35)}$ Professors indicate that their work is that of being facilitators of learning because students are the principal responsible subjects in the process, but they offer them the necessary aids to favor said process. ${ }^{(36)}$

In support of the previously stated, higher levels of student satisfaction have been observed when meetings with professors focus on their learning needs. ${ }^{(37)}$ Even so, professors are most critical with themselves, this premise is reflected on a study that evaluated the competencies of nursing educators according to their self-evaluations and that of the students, which recognized their abilities for teaching, but with weaknesses in the assessment aspects. ${ }^{(38)}$ This particular aspect presents a duality between being a professor and being a nurse in which the professional experience in nursing provides bases to guide future nurses, without ignoring their needs for growing in the pedagogic aspects that will support the didactic part in teaching the discipline. ${ }^{(39)}$

Given that preparing a nursing professional is a complex task requiring skills from the professors related not only with their disciplinary knowledge, but with the abilities acquired from their own experience regarding being, nursing education has voids that do not correspond to students' expectations, such as the professors' pedagogic formation, behavior and responsibility with relation to students' learning. Hence, the challenge here lies in exploring what pedagogic skills the nurses need to perform significantly in teaching.

Research trends in this concept are descriptive, nevertheless, scientific literature reports the importance of advancing to studies with levels of evidence of predictive, experimental, or mixed nature. Some questions that can guide the educational research in nursing are: What are the professor's professional skills and behaviors that 
favor student learning? What is the relationship between the professor's professional skills and the student's perception of learning? What is the effect of the professor's behavior on the nursing student's learning experience?

\section{Pedagogic relationship}

For this concept, research was found describing the positive and negative factors of this relationship in the formation of nurses, and frame it within the relationships of care and its significance, aspects that are particular in the discipline. It starts from the premise that nursing students have the need to develop care abilities, along with the experience of being and feeling cared, through the pedagogic relationship, but in spite of the expressed necessity, diverse studies expose that professors ignore the effective needs of students and their importance in learning, in turn, students advocate for the warmth of the relationship. ${ }^{(40,41)}$ Pedagogic relationships can generate feelings that can sensitize, approximate, or distance professors and students in the daily routine of teaching and learning of being and doing nursing. ${ }^{(42)}$

A positive experience between professors and students is perceived when each has a shared understanding of the other, when the professor is motivating, shows respect, is kind, and reliable to students, and these characteristics manage to reduce anxiety levels of students during the practices. This shows that an effective relationship helps to modify the student's behavior, ensuring positive results in the learning process. ${ }^{(43,44)}$ practice skills learned in lab, and interact with patients, families, and other nurses. Although students look forward to these experiences, they often feel intimated and anxious about them. Clinical instructors play an important role in this experience and can either help or hinder student learning and self-efficacy. Using Bandura's Social Learning Theory as foundation, this descriptive study examined the relationship between perceived instructor effectiveness and student selfefficacy. Data were collected from a BSN school of nursing at a Midwestern USA comprehensive masters university. The instruments used were the Nursing Clinical Teacher Effectiveness Inventory (NCTEI In addition, it was found that a caring professor who suggests ways of improving, identifies the student's strengths and weaknesses, provides positive reinforcement, and corrects without underestimating correlates statistically with students who reported greater self-efficacy in their formation process. ${ }^{(45)}$ It is, therefore, justified that for students, professors represent a model that can have positive or negative significance in the practical experience. ${ }^{(46)}$

A concept that emerges strongly within the pedagogic relationship is trust; some investigations address it and assert that it is a fundamental factor in social relationships with a particular purpose and which helps to guide to an objective, that is, when students perceive that the professor inspires confidence and supports them, help them to visualize themselves as nursing professionals. (47-49) The pedagogic relationship is the base of success in nursing teaching and learning, as stated by Rivera and Medina, ${ }^{(50)}$ presence, empathy, dialogue, disposition, trust, responsibility, and autonomy contribute to establishing ethical and humanizing relationships with students, so that the challenge lies in knowing the association or connecting point between nursing care and that which the professor offers students.

Among the knowledge voids explicit in nursing, literature highlights the importance of identifying positive and negative characteristics in pedagogic relationships intervening in the development of nursing skills in students and describing what behaviors and interactions contribute for the pedagogic relationship to be beneficial for the nursing student's learning. Added to this, research challenges around this phenomenon highlight the importance of conducting descriptive, comparative, and correlational studies that answer aspects, like: What aspects of the pedagogic relationship impact upon learning? What are the behaviors that characterize an effective pedagogic relationship? Do factors exist that are associated 
to or predict effective pedagogic relationships for learning?

\section{Professional skills}

Lastly, as per the professional skills for the discipline, the articles dealt with aspects, like transpersonal, empathic, compassionate and clinical care, the relevance of developing emotional and cultural abilities, which guide in the formation of students in skills for caring. The concept of competence in nursing is manifested through acquiring and developing educational, cultural, moral, investigative, and individual abilities for caring, hence, learning and teaching being and doing nursing carries the imprint of having and developing certain skills in students. (51)

Some publications argue that the formation of students requires technical and affective abilities, which is an aspect that demands more than the mere transmission of contents, it implies incorporating commitment with others, motivation, and empathy. ${ }^{(52)}$ This suggests that the nurse professor's interpersonal and communicative abilities are as important as their clinical knowledge and abilities in learning. $(53,54)$ Learning interpersonal and communicative abilities and caring for themselves is perceived as essential to care for another; although the practice still centers on technical abilities, the formation in human relations has gained relevance. For $75.8 \%$ of the students, the professor's knowledge and experience are the most important aspects, but of these, $73.4 \%$ consider that relational abilities are also primordial. ${ }^{(55,56)}$ nonexperimental design was used in this study. Methods: A total of 586 student nurses from four countries (Greece, the Philippines, India, and Nigeria These interpersonal skills are also related with other skills, like leadership capacity and critical judgment, promoting the "knowing how to analyze". ${ }^{57,58)}$

Furthermore, students who progress in their process of learning professional skills were characterized as being individuals who manage to defend their rights, express their emotions, negotiate and self-plan (16\% variance), as well as being assertive in relationships with others (16\% variance), in acceptance of themselves or of the other person, in facing critique and establishing a two-way communication channel $(60 \%$ variance). ${ }^{(59)}$ Supporting the aforementioned, perceptions of the nursing study plans and curricula, on the challenge of competent cares curros otros como la capacidad de liderezago y el juicio crñi evidence that, in relation to the psycho-emotional dimension, the need exists to implement modifications in the professional training of nurses to rescue the humanistic vision along with the scientific. ${ }^{(60)}$ Added to this is ethics, which is also part of these skills and which is learnt through the professor's example in which their individual beliefs, clinical abilities, and professional commitment become the model to follow, besides promoting critical thought and the decision making capacity in situations that can be ethical dilemmas for students. ${ }^{(61)}$

Definitely, a nursing skill in general is not made explicit; rather, its attributes are addressed or a specific competence is described, which for effects of the research can be observed and analyzed with greater ease. Hence, knowledge voids explicit in literature with respect to this category encourage enhancing the transpersonal, ethical, and humanistic skills of caring in the development of students and inquiring on aspects related with skills for caring that are relevant for the formation of nurses and which favor the teaching - learning process.

Some of the research trends and/or challenges are the exploration and description of the professional competence, especially in its interpersonal aspects: How are professional and interpersonal skills developed? What is needed for the development of these skills? What happens with the interpersonal aspects of the skill?

Additionally, there is the challenge of verifying the way the professor's modelling helps to develop professional skills in students, emphasizing on didactics that favor "learning by doing". In the 
same sense, aimed at the professor's modelling we must inquire on the relationship and influence of the pedagogic relationships in promoting the disciplinary learning. In general, nursing professors need to mediate in situations that involve the technical rationality with the sensitivity of the interpersonal relationship, ${ }^{(42)}$ without dismissing critical judgment; this becomes a challenge within nursing educational research at a moment of the discipline during which curricula has been devised seeking to balance being, knowing, doing, and coexisting in nursing, which is why this must be evaluated in the long term with students prepared with this approach.

Conclusions. The literature review around the thematic area of nursing education related with the professional training distinguishes five large concepts: (1) successful didactics; (2) the caring learning process; (3) the nurse's professor role; (4) pedagogic relationship; and (5) professional skills. With respect to the concept of successful didactics, it was found that it is a broadly addressed theme in nursing research, that is, progress has been made in "how" we can teach to care. Of the didactics presented, it is concluded that students require professor contact and accompaniment through classroom work combined with the use of ICTs, thus, highlighting the importance of Blended Learning (B-Learning); additionally, the use of simulation and problem-based learning is prevalent, which is why it is important to have a long-term follow up of the learning achieved by the students who use them and, lastly, it is necessary to advance on the research level of the reflexive writings, given their usefulness for the formation of students' reflexive and critical thought. One of the research trends in this aspect centers on understanding the way in which students develop care abilities in direct contact with people.

About the concept of the caring learning process, the importance of the formation of the student's reflexive and critical thought can be highlighted, considering that the teaching processes acquire a situated and problematizing nature of the context in which the nursing practice takes place. Added to the aforementioned, it is stressed that the teaching - learning process is, above all, complex and lacks being linear, which encourages bearing in mind the different learning styles of students and their study habits. Currently, nursing students are characterized by being active subjects within their teaching - learning process, being a search for greater political participation to achieve greater social insertion and recognition. This projection is the result of a critical reflexive focus on the formation process for which it must be based on new communication and organizational possibilities, and relationships of inter-subjectivity and care.

With respect to the concept of the nurse's professor role, research has been aimed at the significance of the nurse being and at the competence of the professor being. Evidencing that preparing a nursing professional is a complex task that requires of professors skills related not only with their disciplinary knowledge, but also requires attitudinal, pedagogic, and ethical skills centered on student learning. Hence, some knowledge voids inherent to this concept call to explore which pedagogic skills are needed by nurses to perform significantly in teaching.

Literature demonstrates that the pedagogic relationship is the base of success of the teaching - learning process in nursing; it highlights the characteristic traits of the professor - student relationship that strengthen the formation of the traits appertaining to nursing care and which contribute to the formation of interpersonal, ethical, and humanizing skills in nursing students. The knowledge voids explicit in nursing literature underscore the importance of identifying the positive and negative characteristics prevalent in the pedagogic relationships intervening in the development of nursing skills in students and describing which behaviors and interactions contribute for the pedagogic relationship to be beneficial for the nursing student's learning.

Within the concept of professional skills for the discipline, the articles worked aspects, like transpersonal, empathic, compassionate, and 
clinical care; relevance of developing emotional and cultural abilities; importance of strengthening interpersonal, ethical, and humanistic skills in nurse formation, bearing in mind that the object of nursing is that of caring for the human being's health experience. Hence, knowledge voids explicit in literature with respect to this category urge strengthening in nurse formation the transpersonal, ethical, and humanistic skills of care and inquiring on aspects related to the skill for caring relevant for the formation of nurses and which favor the teaching - learning process.

Some research trends and/or questions that emerge from the scientific literature and which can guide the educational research in nursing are: What are the professional skills and behaviors of the professor that favor student learning? What is the relationship between the professor's professional skills and the student's perception of learning? What is the effect of the professor's behavior on the nursing student's learning experience? What aspects of the pedagogic relationship influence upon learning? What are the behaviors that characterize an effective pedagogic relationship? Do factors exist that associate or predict effective pedagogic relationships for learning? How are professional and interpersonal skills developed? What is needed to develop these skills? What happens with the interpersonal aspects of the skill? 


\section{References}

1. Arreola Caro MI. Evaluación holística del modelo pedagógico del Centro Universitario de los Valles de la Universidad de Guadalajara [Dissertation]. Valladolid (España): Universidad de Valladolid; 2012. Available from: https://core. ac.uk/download/pdf/61503381.pdf

2. Flórez MC. Retos de la formación pedagógica de los futuros profesionales de enfermería. En: Grupo cuidado de la salud Universidad Libre de Cali. Cuaderno pedagógico de enfermería. Cali (Colombia): Ed. Feriva SA; 2010. p. 31-6

3. Gómez EM. La enfermería en Colombia: una mirada desde la sociología de las profesiones. Aquichan. 2012; 12(1):42-52.

4. Salgado J, Sanhueza O. Enseñanza de la Enfermería y relación docente asistencial en el marco educacional y sanitario chileno. Invest. Educ. Enferm. 2010; 28(2):258-66.

5. Castillo S, Vessoni RV. La relación tutor-estudiante en las prácticas clínicas y su influencia en el proceso formativo del estudiante de Enfermería. Educare21. 2007; 38:1-7.

6. Guirao JA, Olmedo A, Ferrer E. El artículo de revisión. Rev. Iberoamericana de Enfermería Comunitaria. 2008; (1):1-6.

7. Joanna Briggs Institute. New JBI Levels of Evidence. 2013 [cited 10 Aug 2018]. Available from: http://joannabriggs. org/assets/docs/approach/JBI-Levels-of-evidence_2014.pdf

8. Guba EG. Criteria for assessing the trustworthiness of naturalistic inquiries. Educ. Communi. Technol. J. 1981; 29:75-91.

9. Hernández Sampieri R, Fernández C, Baptista M. Metodología de la investigación. 6th Ed. México: McGraw-Hill; 2014.

10. Ironside P. Enabling Narrative Pedagogy: Inviting, Waiting, and Letting Be. Nurs. Educ. Perspect. 2014; 35(4):212-18.

11. Chan Z. Students' and experts' perspectives on three learning and teaching activities. Nurse Educ. Today. 2014; 14(5):449-54.

12. Soares A, Silveira A, Silveira B, Vieira J, Souza L, Alexandre L, et al. O diário de campo utilizado como estratégia de ensino e instrumento de análise do trabalho da enfermagem. Rev. Eletr. Enf. 2011; 13(4):665-70.

13. Rodríguez Jiménez $\mathrm{S}$, Cárdenas Jiménez $\mathrm{M}$, Blando Palomino A. Los diarios reflexivos en la tutoría clínica de enfermería: Significados atribuidos por los tutorados. Enferm. Univ. 2012; 9(4):9-20.

14. Coleman D, Willis D. Reflective writing: The student nurse's perspective on reflective writing and poetry writing. Nurse Educ. Today. 2015; 35(7):906-11.

15. Falconí Morales C, Brito Santacruz CJ, Verkovitch I. Integración de la enseñanza de la práctica de enfermería basada en la evidencia científica. Aquichan. 2015; 15(4):541-53.

16. Eterovic Díaz C, Stiepovich Bertoni J. Enfermería basada en la evidencia y formación profesional. Cienc. Enferm. 2010; 16(3):9-14.

17. Zeleníková R, Beach M, Ren D, Wolff E, Sherwood P. Faculty Perception of the Effectiveness of EBP Courses for Graduate Nursing Students. Worldviews Evid Based Nurs. 2014; 11(6):401-13.

18. Silva AP, Pedro EN. Autonomy in Nursing Students Process of Knowledge Construction: the Educational Chat as a Teaching Tool. Rev. Latino-Am. Enfermagem. 2010; 18(2):210-16.

19. Francisco J. Calidad en entornos virtuales de aprendizaje. Compendium. 2012; (29):97-107.

20. Boude Ó, Ruiz MT. Las TIC: propuesta para el aprendizaje de enfermería basado en problemas. Aquichan. 2008; 8(2):227-42.

21. Pourghaznein T, Sabeghi H, Shariatinejad K. Effects of e-learning, lectures, and role playing on nursing students' knowledge acquisition, retention and satisfaction. Med. J. Islam. Repub. Iran. 2015; 29:162-72.

22. Shin IS, Kim JH. The effect of problem-based learning in nursing education: A meta-analysis. Adv. Health Sci. Educ. Theory Pract. 2013; 18(5):1103-20. 
23. Raurell M, Olivet J, Romero A, Malagón MC, Patiño J, Baltasar A. Case-Based Learning and Simulation: Useful Tools to Enhance Nurses' Education? Nonrandomized Controlled Trial. J. Nurs. Scholarsh. 2015; 47(1):34-42.

24. De la Horra Gutiérrez I, Beneit Montesino JV. La simulación clínica como herramienta de evaluación de competencias en la formación de enfermería. Reduca. 2010; 2(1):549-80.

25. Yeun EJ, Bang HY, Ryoo EN, Ha EH. Attitudes toward simulation based learning in nursing students: An application of Q methodology. Nurse Educ. Today. 2014; 34(7):1062-8.

26. Dahl H, Eriksen K. Students' and teachers' experiences of participating in the reflection process "THINK". Nurse Educ. Today. 2016; 36:401-6.

27. Bardallo MD, Medina JL, Zabalegui A. Dialogic Learning in the Training of Nurses. Creat. Educ. 2013; 4(4):283-6.

28. Rodriguez-García M, Medina-Moya JL. El legado del cuidado como aprendizaje reflexivo. Rev. Latino-Am. Enfermagem. 2016; 24:e2711.

29. López Aguado M, Silva Falchetti E. Estilos de aprendizaje. Relación con motivación y estrategias. Rev. Estilos Aprendiz. 2009; 4(4):43-66.

30. Canalejas MC, Martínez ML, Pineda MC, Vera ML, Soto M, Martín A, et al. Estilos de aprendizaje en los estudiantes de enfermería. Educ. Méd. 2005; 8(2):33-40.

31. Parra M, Becerra F. Estilo cognitivo en estudiantes universitarios de la carrera de enfermería de la Universidad Nacional de Colombia, 2009. Av. Enferm. 2013; 31(2):53-64.

32. Herrera Torres L, Lorenzo Quiles O. Estrategias de aprendizaje en estudiantes universitarios. Un aporte a la construcción del Espacio Europeo de Educación Superior. Educ. Educadores. 2009; 12(3):75-98.

33. Silva KL, Sena RR. La educación de enfermería: búsqueda de la formación crítica y reflexiva y de las competencias profesionales. Rev. Latino-Am Enfermagem. 2006; 14(5):1-7.

34. Solvoll BA, Heggen KM. Teaching and learning care - Exploring nursing students' clinical practice. Nurse Educ. Today. 2010; 30(1):73-77.

35. Bettancourt L, Muñoz L, Barbosa M, Dos M. El docente de enfermería en los campos de práctica clínica : un enfoque fenomenológico. Rev. Latino-Am. Enfermagem. 2011; 19(5):1-9.

36. González MA, Badía MC, Font CM. La identidad del académico de enfermería: entre la docencia y la investigación. Texto Contexto Enferm. 2014; 23(2):241-9.

37. Saarikoski M, Warne T, Kaila P, Leino Kilpi $\mathrm{H}$. The role of the nurse teacher in clinical practice: An empirical study of Finnish student nurse experiences. Nurse Educ. Today. 2009; 29(6):595-600.

38. Salminen L, Minna S, Sanna K, Jouko K, Helena LK. The competence and the cooperation of nurse educators. Nurse Educ. Today. 2013; 33(11):1376-81.

39. Sebold LF, Carraro TE. La práctica pedagógica del docente en enfermería: una revisión integradora de la literatura. Enferm. Global. 2011; 10(22):1-12.

40. Bardallo Porras L, Rodríguez Higueras E, Chacón Sánchez MD. La relación tutorial en el Practicum de Enfermería. Rev. Docencia Univ. REDU. 2012; 10: 211-28.

41. Dobinson A. Personal tutor encounters: understanding the experience. Nurs. Stand. 2006; 20(50):35-42.

42. Terra MG, Gonçalves LHT, Santos EKA, Erdmann AL. Sensibility in the relations and interactions of teaching and learning to be and do nursing. Rev. Lat-Am Enfermagem. 2010; 18(2):203-9.

43. Eller LS, Lev EL, Feurer A. Key components of an effective mentoring relationship: A qualitative study. Nurse Educ. Today. 2014; 34(5):815-20.

44. Kestenberg CCF, Reis MM dos SA, Motta W de C, Caldas MF, Rodrigues DM da C. Cuidando do estudante e ensinando relações de cuidado de enfermagem. Texto Contexto Enferm. 2006; 15(spe):193-200.

45. Rowbotham M, Owen RM. The effect of clinical nursing instructors on student self-efficacy. Nurse Educ. Pract. 2015; 15(6):561-6.

46. Illesca M, Cabezas M, Nuin C, Jürschick P. Competencias del docente clínico enfermera/o, Universidades Lleida (España) y La Frontera (Chile): Percepción del estudiante. Cienc. Enferm. 2010; 16(2):99-106.

47. Ross J, Head K, King L, Perry PM, Smith S. The personal development tutor role: an exploration of student and lecturer experiences and perceptions of that relationship. Nurse Educ. Today. 2014; 34(9):1207-13. 
48. Zapata J, Rojas L, Gómez A. Modelado de la relación de confianza. Educ. Educadores. 2010; 13(1):77-90.

49. Labrague LJ, Mcenroe Petitte DM, Papathanasiou IV, Edet OB, Arulappan J. Impact of Instructors' Caring on Students' Perceptions of Their Own Caring Behaviors. J. Nurs. Scholarsh. 2015; 47(4):338-46.

50. Rivera Álvarez LN, Medina Moya JL. La relación pedagógica estudiante-enfermera: un estudio hermenéuticofenomenológico. Texto Contexto Enferm. 2017; 26(2):e00560016

51. Jafari H, Mohammadi E, Ahmadi F, Kazemnejad A, Shorofi SA. The experience of nursing instructors and students on professional competency of nursing academic staff: a qualitative study. Glob. J. Health Sci. 2014; 6(4):128-35.

52. Lopes RCC, Azeredo ZAS, Rodrigues RMC. Relational skills: needs experienced by nursing students. Rev. LatinoAm. Enfermagem. 2012; 20(6):1081-90.

53. Bernart J. Ênfase nas relações interpessoais na formação do enfermeiro sob o paradigma ético-humanista. Trab. Educ. Saúde. 2013; 11(3): 633-657.

54. Khomeiran RT, Yekta ZP, Kiger AM, Ahmadi F. Professional competence: Factors described by nurses as influencing their development. Int. Nursing Rev. 2006; 53(1):66-72.

55. Ali WG. Caring and Effective Teaching Behavior of Clinical Nursing Instructors in Clinical Area as Perceived by Their Students. J. Nurs. Educ Pract. 2012; 3(7):15-27.

56. Włoszczak-Szubzda A, Jarosz MJ. Professional communication competences of nurses. Ann. Agric. Environ. Med. 2012; 19(3):601-7.

57. Gunther M, Evans G, Mefford L, Coe TR. The relationship between leadership styles and empathy among student nurses. Nurs. Outlook. 2007; 55(4):196-201.

58. Silva KL, Sena RR. Integralidade do cuidado na saúde: indicações a partir da formação do enfermeiro. Rev. Esc. Enferm. USP. 2008; 42(1):48-56.

59. González N, Lobato C. Evaluación de las competencias sociales en estudiantes de enfermería. Bordón. 2008; 60(2):91-105.

60. Nunes Emanuelle CDA, Silva Luzia WS, Pires Eulina POR. La enseñanza superior de enfermería: implicaciones de la formación profesional para el cuidado transpersonal. Rev. Latino-Am. Enfermagem. 2011; 19(2):252-60.

61. Borhani F, Alhani F, Mohammadi E, Abbaszadeh A. Professional Ethical Competence in nursing: the role of nursing instructors. J. Med. Ethics Hist. Med. 2010; 3:1-8. 